\title{
THE APPLICATION OF POLYMERASE CHAIN REACTION FOR CHARACTERISING STRAINS OF PSEUDOMONAS SYRINGAE ISOLATED FROM NEW ZEALAND RIVERS
}

\author{
J.L. VANNESTE ${ }^{1}$, D.A. CORNISH ${ }^{1}$, J. YU $^{1}$ and C.E. MORRIS ${ }^{2}$ \\ ${ }^{I}$ The New Zealand Institute for Plant \& Food Research Limited, Ruakura \\ Research Centre, Private Bag 3123, Hamilton 3240, New Zealand \\ ${ }^{2}$ INRA, UR 407 Pathologie Végétale, F-84140 Montfavet, France
}

Corresponding author: JVanneste@hortresearch.co.nz.

\begin{abstract}
Pseudomonas syringae is a complex group of bacteria, which comprises nine different genomospecies and over 50 pathovars. Strains of $P$. syringae have been isolated from some rivers and lakes in New Zealand. To determine whether these waterways act as reservoirs of plant pathogenic bacteria, 15 strains of $P$. syringae isolated from the Waikato River and Whakapapanui stream have been further characterised using several polymerase chain reaction (PCR) protocols. Five of those 15 strains belong to genomospecies 1 , which comprises $P$. syringae pv. syringae, but none belongs to genomospecies 2 . The protocol for detection of $P$. syringae pv. papulans was modified and is now specific for this pathovar. The identity of a strain isolated from the Waikato River as being $P$. syringae pv. atrofaciens has yet to be confirmed. None of the 15 strains studied belongs to the pathovars papulans, actinidiae, tagetis, helianthii or theae. Keywords: bacterial ecology, genomospecies, papulans, actinidiae.
\end{abstract}

\section{INTRODUCTION}

Pseudomonas syringae is an important and complex taxonomic group that includes all fluorescent pseudomonad strains that are oxidase negative, arginine dihydrolase negative and induce a hypersensitive reaction when injected into tobacco plants (Palleroni 1984). Pseudomonas syringae includes many economically significant plant-pathogenic bacteria. A large number of plant species can be infected by strains of $P$. syringae, but every strain of $P$. syringae shows some host specificity and induces disease only in some plant species. To take into account the host specificity of the different strains of $P$. syringae, the word pathovar (pv.) has been coined. There are about 50 pathovars described for $P$. syringae. Based on DNA homology $P$. syringae is actually composed of at least nine different species, called "genomospecies" (Gardan et al. 1999; Marques et al. 2008). Since strains from different genomospecies cannot be distinguished phenotypically, eight genomospecies have not been named and the pathovar system of nomenclature is still commonly used. Unfortunately, strains of different pathovars cannot be distinguished by biochemical or physiological characteristics alone. Identification of a strain of $P$. syringae at the pathovar level usually requires a combination of physiological, biochemical and serological tests and pathogenicity assays. Because such a characterisation is difficult and laborious, many authors have tried to develop molecular tools such as polymerase chain reaction (PCR) protocols to identify strains of $P$. syringae that belong to one pathovar or one genomospecies (e.g. Musa et al. 2001; Kerkoud et al. 2002; Koh \& Nou 2002; Kong et al. 2004).

Riffaud \& Morris (2002) isolated a pathogen of cantaloupe, P. syringae pv. aptata, from retention basins used for irrigation of cantaloupe. The identification of such a source of inoculum is very important for the development of control methods. This is especially true of plant pathogenic bacteria for which there are only limited control 
options. Pseudomonas syringae has been isolated from some rivers and lakes from the North Island of New Zealand (Vanneste et al. 2008). The aim of this research was to determine whether these waterways act as a reservoir of plant pathogenic bacteria. The approach taken was to develop a suite of methods to identify the pathovar or genomospecies of the strains of $P$. syringae isolated from the Waikato River and the Whakapapanui Stream. Since pathogenicity tests on several dozens of potential host plants is not practical, PCR protocols developed for specific identification of some genomospecies or pathovars were used.

\section{MATERIALS AND METHODS}

\section{Bacterial strains}

Ten strains isolated from the Whakapapanui Stream (Tongariro National Park) and five strains isolated from the Waikato River (Hamilton), described previously (Vanneste et al. 2008) as strains of $P$. syringae (based on their ability to produce a fluorescent pigment on a modified King's B medium (KBC; Mohan \& Schaad 1987) and cause a hypersensitive reaction when infiltrated into a tobacco plant, the absence of a cytochrome c oxidase and their inability to utilise arginine) were used in this study.

The other strains of $P$. syringae used in this study were obtained from the International Collection of Microorganisms from Plants (ICMP) held by Landcare Research New Zealand. They were used as positive or negative controls in the different PCR protocols and are presented in Table 1. They were maintained on King's B medium (King et al. 1954 ) at $28^{\circ} \mathrm{C}$. Strains of other genera were also included in some of the experiments as negative controls: Erwinia amylovora ICMP 8865, Pantoea agglomerans P10c (Vanneste et al. 2002), Pseudomonas fluorescens A506 (Lindow et al. 1996) and Xanthomonas campestris pv. pruni 2.38 (J.L. Vanneste, laboratory collection).

TABLE 1: Strains of Pseudomonas syringae used as positive or negative controls in the polymerase chain reactions.

\begin{tabular}{|c|c|c|c|c|}
\hline Species or pathovar & Strains & Host plant & $\begin{array}{l}\text { Year of } \\
\text { isolation }\end{array}$ & $\begin{array}{l}\text { Geographical } \\
\text { origin }\end{array}$ \\
\hline P. syringae pv. syringae & ICMP 3523 & $\begin{array}{l}\text { Lycopersicum } \\
\text { esculentum }\end{array}$ & 1970 & Australia \\
\hline P. s. pv. aptata & ICMP 459 & Beta vulgaris & 1959 & USA \\
\hline P. s. pv. lapsa & ICMP 3947 & Zea sp. & Not known & Not known \\
\hline P. s. pv. papulans & ICMP 3881 & Not known & Not known & USA \\
\hline P. s. pv. papulans & ICMP 4044 & Malus domestica & 1968 & Canada \\
\hline P.s.pv. pisi & ICMP 2452 & Pisum sativum & 1969 & New Zealand \\
\hline P. s. pv. atrofaciens & ICMP 4394 & Triticum aestivum & 1968 & New Zealand \\
\hline P.s.pv. panici & ICMP 3955 & Not known & Not known & Not known \\
\hline P. s. pv. japonica & ICMP 6305 & Hordeum vulgare & 1951 & Japan \\
\hline P. s. pv. helianthi & ICMP 3549 & Helianthus annuus & 1969 & New Zealand \\
\hline P. s. pv. tagetis & ICMP 4091 & Tagetes erecta & 1972 & Zimbabwe \\
\hline P. s. pv. theae & ICMP 3923 & Camellia sinensis & 1970 & Japan \\
\hline P.s. pv. theae & ICMP 3934 & Camellia sinensis & Not known & Japan \\
\hline P.s. pv. actinidiae & ICMP 9617 & Actinidia deliciosa & 1984 & Japan \\
\hline
\end{tabular}

\section{Characterisation of the bacteria by Polymerase Chain Reaction (PCR)}

All bacterial strains were characterised by PCR using about $20 \mathrm{ng}$ of total DNA per reaction. Total DNA was isolated with a cell disruptor FastPrep ${ }^{\circledR}-24$ from MP ${ }^{\mathrm{TM}}$ using the ZR fungal/bacterial DNA kit ${ }^{\mathrm{TM}}$ from Zymo Research, USA. PCRs were performed 
on an Eppendorf Mastercycler® Gradient. The PCRs were carried out in $30 \mu \mathrm{l}$ containing $1 \mu \mathrm{l}$ of the DNA of the strain of interest, $2 \mu \mathrm{l}$ of primers ( $1 \mu \mathrm{l}$ of each primer, corresponding to $10 \mu \mathrm{M}), 2 \mu \mathrm{l}$ of $\mathrm{dNTP} \operatorname{mix}(2.5 \mathrm{mM}$ each) (supplied with the DNA polymerase), $3 \mu \mathrm{l}$ of 10× PCR buffer supplied with the DNA polymerase, $21.8 \mu \mathrm{l}$ of sterilised distilled water and $0.2 \mu \mathrm{l}$ (corresponding to 1 unit) of $i$-Taq ${ }^{\mathrm{TM}}$ from INtRON Biotechnology, Inc. A negative control, in which the DNA solution was replaced by the same volume of water, and a positive control, in which the DNA was that of a strain that gave a positive reaction, were used for each experiment.

The PCR products were separated by horizontal gel electrophoresis using a Biokey Super Screener 120 Electrophoresis system (Innovation Sciences Limited, Dunedin, New Zealand) on $1 \%$ or $2 \%$ agarose (depending on the size of the PCR product) containing $100 \mathrm{ng} / \mathrm{ml}$ of ethidium bromide. From each reaction, 15 to $30 \mu \mathrm{l}$ were loaded on the agarose gel and the DNA bands were visualised under UV light. On each gel, a DNA ladder (1 kb Plus DNA Ladder or 100 bp DNA Ladder from Invitrogen ${ }^{\mathrm{TM}}$ ) was used. The primers used in this study are presented in Table 2. Unless stated otherwise, the PCR programmes used to determine whether a strain belonged to genomospecies 1 or 2 or to pathovar papulans were those described by Kerkoud et al. (2002). The programmes used to determine whether a strain belong to the pathovar aptata, the pathovar actinidiae or the pathovars helianthii or tagetis were those described by Musa et al. (2001), Koh \& Nou (2002) and Kong et al. (2004), respectively.

TABLE 2: Name, size of DNA product in base pairs (bp), specificity and reference of the Polymerase Chain Reaction primers used in this study.

\begin{tabular}{|c|c|c|c|}
\hline Name & $\begin{array}{c}\text { Size of } \\
\text { product (bp) }\end{array}$ & Specificity & Reference \\
\hline hrpL1 and hrpL2 & 631 & genomospecies 1 and 2 & Kerkoud et al. 2002 \\
\hline Pap1 and Pap2 & 242 & P. syringae pv. papulans & Kerkoud et al. 2002 \\
\hline hrpZf1 and hrpZr2 & 900 & P. syringae pv. aptata & Musa et al. 2001 \\
\hline $\begin{array}{l}\text { TAGTOX-9FP1 and } \\
\text { TAGTOX-9FR1 }\end{array}$ & 507 & $\begin{array}{l}\text { P. syringae pv. tagetis and } \\
\text { pv. helianthi }\end{array}$ & Kong et al. 2004 \\
\hline $\begin{array}{l}\text { TAGTOX-10FP1 and } \\
\text { TAGTOX-10FR } 1\end{array}$ & 733 & $\begin{array}{l}\text { P. syringae pv. tagetis and } \\
\text { pv. helianthi }\end{array}$ & Kong et al. 2004 \\
\hline $\begin{array}{l}\text { Forward primer and } \\
\text { Reverse primer }\end{array}$ & 492 & P. syringae pv. actinidiae & Koh \& Nou 2002 \\
\hline JLVLf3 and JLVLr8 & 280 & Genomospecies 2 & $\begin{array}{l}\text { J.L. Vanneste, } \\
\text { unpublished data }\end{array}$ \\
\hline
\end{tabular}

\section{RESULTS AND DISCUSSION}

None of the non $P$. syringae strains gave a positive reaction with any of the protocols (set of primers and corresponding PCR programme) used or developed in this study. Of the 15 strains analysed, four strains isolated from the Waikato River and one strain isolated from Whakapapanui stream gave a positive reaction with the primers hrpL1 and hrpL2, which are specific for strains of genomospecies 1 and 2. No PCR product was detected when the total DNA of those five strains was used in a PCR experiment using the primers JLVLf3 and JLVLr8, which lead to a $280 \mathrm{bp}$ DNA band from all and only the strains belonging to genomospecies 2 . Therefore, those five strains most probably belong to genomospecies 1 , which is represented by P. syringae pv. syringae. However, they could belong to any of the pathovars that constitute genomospecies 1 , which include the pathovars syringae, aptata, lapsa, papulans, pisi, atrofaciens, aceris, dysoxyli, panici or japonica. This also indicates that no strains of genomospecies 2 , which includes the pathovars phaseolicola, morsprunorum, eriobotryae, tabaci, lachrymans, sesami, ulmi, mori, lachrymans, cerasicola and glycinea were present in this sample. However, this 
was a limited sample of strains, and those strains were isolated using the medium KBC, which might not allow strains of all pathovars to grow equally well (Morris et al. 2008; Vanneste et al. 2008).

When the protocol described by Musa et al. (2001) to identify P. syringae pv. aptata was used, in addition to $P$. syringae pv. aptata ICMP 459, strains of $P$. syringae pv. pisi ICMP 2452, atrofaciens ICMP 4394, panici ICMP 3955 and japonica ICMP 6305 also gave a PCR product of ca $900 \mathrm{bp}$. One of the strains isolated from the Waikato River gave a positive reaction with this PCR protocol. However, when leaves of silver beet, which is one of the host plant of $P$. syringae pv. aptata (Koike et al. 2003), were inoculated with this strain, no symptoms were observed after 10 days incubation at room temperature (data not shown). This suggests that this strain is not a strain of P. syringae pv. aptata. This will be confirmed with further pathogenicity tests on other potential host plants and by multilocus sequencing typing (MLST). Sarkar \& Guttman (2004) have shown that analysis of the DNA sequence of seven housekeeping genes using MLST represents another powerful tool for the characterisation of strains of $P$. syringae.

Another of the strains isolated from the Waikato River, and previously identified as belonging to genomospecies 1 , was positive when using the protocol described as specific for $P$. syringae pv. papulans (Kerkoud et al. 2002; Vanneste \& Yu 2006). However, using a range of strains of different pathovars, $P$. syringae pv. atrofaciens ICMP 4394 also gave a positive reaction with this protocol. By increasing the annealing temperature from $64^{\circ} \mathrm{C}$ to $75^{\circ} \mathrm{C}$, only the strains of $P$. syringae pv. papulans gave a DNA product of the expected size (242 bp). To make sure that this modified protocol was specific for all strains of $P$. syringae pv. papulans, it was tested with the 17 strains of this pathovar available in New Zealand. All of them gave a positive result (data not shown). None of the other strains tested including the strain from the Waikato river and $P$. syringae pv. atrofaciens ICMP 4394 gave a positive reaction with this modified protocol. Therefore, this Waikato river strain is not a strain of $P$. syringae pv. papulans. To establish whether this strain belongs to the pathovar atrofaciens, it will be necessary to carry out a pathogenicity assay on wheat plants, the host plant of $P$. syringae pv. atrofaciens.

None of the strains isolated reacted positively with the protocol specific for $P$. syringae pv. actinidiae (Koh \& Nou 2002). Using this same protocol, a positive reaction, i.e. a 220 bp band of DNA, was detected when the total DNA of the two strains of $P$. syringae pv. theae (ICMP 3923, ICMP 3934) was used. The pathovars theae and actinidiae have initially been put into genomospecies 8 and 3, respectively. However, they might belong to the same genomospecies, which would be consistent with strains of those two pathovars giving a positive result with the protocol developed by Koh \& Nou (2002) and with those strains showing a very high level of similarity at the DNA level for the genes $h r p \mathrm{~A}, h r p \mathrm{~B}, h r p \mathrm{~S}$ and $h r p \mathrm{Z}$ (Inoue \& Takikawa 2006) and for the genes $h r p \mathrm{~L}$, $23 \mathrm{~S}$ rDNA and for the ITS sequences (data not shown). If the protocol for detection of $P$. syringae pv. actinidiae also detects strains of $P$. syringae pv. theae, then none of the strains isolated from either the Waikato River or the Whakapapanui Stream were $P$. syringae pv. actinidiae or $P$. syringae pv. theae. None of the strains tested gave a positive response when PCR protocols developed by Kong et al. (2004) specific for $P$. syringae pv. tagetis, and $P$. syringae pv. helianthi were used. While strains of P. syringae pv. helianthi have been isolated in New Zealand, $P$. syringae pv. tagetis is listed by MAF Biosecurity New Zealand as an unwanted organism. It is therefore encouraging that no such strain was detected in the present sample.

This study confirmed that strains of plant pathogenic bacteria similar to those found on cultivated plants (strains of genomospecies 1) are present in New Zealand waterways. The research has also demonstrated that none of the strains tested were $P$. syringae pv. papulans, $P$. syringae pv. actinidiae or $P$. syringae pv. tagetis, which are listed as unwanted organisms by MAF Biosecurity New Zealand. A close relationship at the DNA level between strains of $P$. syringae pv. actinidiae and $P$. syringae pv. theae is supported by the results obtained in the present study. It was also shown that some of the PCR protocols published as pathovar specific were actually not specific. An important outcome of the 
present study is that one of these protocols has been slightly modified such that it is now specific for the detection of $P$. syringae pv. papulans, an organism labelled as unwanted by MAF Biosecurity New Zealand.

In conclusion, of the 15 strains isolated from the Waikato River and Whakapapanui stream, none were pv. papulans, actinidiae, tagetis, helianthii or theae, but five strains were identified as being from genomospecies 1. Further characterisation of one of these strains suggests it may be pv. atrofaciens, but additional investigations are needed to confirm this. Some strains could not be characterised due to the limited number of protocols available and by the specificity of these protocols. A further analysis of these strains using different tools such as MLST might provide more information about their identity. However, strains of $P$. syringae that do not belong to any of the pathovars already described are found regularly (Gilbert et al. 2009), and it would not be surprising if such strains were present in the Waikato River and Whakapapanui stream samples. The identification at the pathovar level of strains present in waterways in New Zealand will help to better understand the link between $P$. syringae and the water cycle, as initially proposed by Morris et al. (2007), and might help to develop control strategies for some of these pathogens.

\section{ACKNOWLEDGEMENTS}

We thank The New Zealand Institute for Plant \& Food Research Limited (formerly HortResearch) for their support.

\section{REFERENCES}

Gardan L, Shafik H, Belouin S, Broch R, Grimont F, Grimont PA 1999. DNA relatedness among the pathovars of Pseudomonas syringae and description of Pseudomonas tremae sp. nov. and Pseudomonas cannabina sp. nov. (ex Sutic and Dowson 1959). International Journal of Systematic Bacteriology 49: 469-78.

Gilbert V, Legros F, Maraite H, Bultreys A 2009. Genetic analyses of Pseudomonas syringae isolates from Belgian fruit orchards reveal genetic variability and isolatehost relationship within the pathovar syringae, and help identify both races of the pathovar morsprunorum. European Journal of Plant Pathology 124: 199-218.

Inoue Y, Takikawa Y 2006. The $h r p Z$ and $h r p A$ genes are variable, and useful for grouping Pseudomonas syringae bacteria. Journal of General Plant Pathology 72: 26-33.

Kerkoud M, Manceau C, Paulin J-P 2002. Rapid diagnosis of Pseudomonas syringae pv. papulans, the causal agent of blister spot of apple, by polymerase chain reaction using specifically designed $h r p L$ gene primers. Phytopathology 92: 1077-1083.

King EO, Ward MK, Raney DE 1954. Two simple media for the demonstration of pyocyanin and fluorescin. Journal of Laboratory Clinical Medicine 44: 301-307.

Koh JK, Nou IS 2002. DNA markers for identification of Pseudomonas syringae pv. actinidiae. Molecules and Cells 13: 309-314.

Koike ST, Henderson DM, Bull CT, Goldman PH, Lewellen RT 2003. First report of bacterial leaf spot on Swiss chard caused by Pseudomonas syringae pv. aptata in California. Plant Disease 87: 1397.

Kong H, Patterson CD, Zhang W, Takikawa Y, Suzuki A, Lydon J 2004. A PCR protocol for the identification of Pseudomonas syringae pv. tagetis based on genes required for tagetitoxin production. Biological Control 30: 83-89.

Lindow SE, Mc Gourty G, Elkins R 1996. Interactions of antibiotics with Pseudomonas fluorescens strain A506 in the control of fire blight and frost injury to pear. Phytopathology 86: 841-848.

Marques ASB, Marchaison A, Gardan L, Samson R 2008. BOX-PCR-based identification of bacterial species belonging to Pseudomonas syringae $-P$. viridiflava group. Genetics and Molecular Biology 31: 106-115.

Mohan SK, Schaad NW 1987. An improved agar plating assay for detecting Pseudomonas syringae pv. syringae and $P$. s. pv. phaseolicola in contaminated bean seed. Phytopathology 77: 1390-1395. 
Morris CE, Kinkel LL, Xiao K, Prior P, Sands DC 2007. Surprising niche for the plant pathogen Pseudomonas syringae. Infection, Genetics and Evolution 7: 84-92.

Morris CE, Sands DC, Vinatzer BA, Glaux C, Guilbaud C, Buffiere A, Yan S, Dominguez H, Thompson BM 2008. The life history of the plant pathogen Pseudomonas syringae is linked to the water cycle. The International Society for Microbial Ecology Journal 1: 1-14.

Musa AR, Minardi P, Mazzuchi U 2001. Identification and expression of the Pseudomonas syringae pv. aptata hrpZ $\mathrm{Psa}_{\mathrm{Pa}}$ gene which encodes an harpin elicitor. Anthonie van Leeuwenhoek 79:61-71.

Palleroni N J, 1984. Family I. Pseudomonadacae. In Krieg R, Holt JG ed. Bergey's Manual of Systemic Bacteriology, Vol. 1. Williams \& Wilkins, London, UK. Pp. 141-219.

Riffaud CM-H, Morris CE 2002. Detection of Pseudomonas syringae pv. aptata in irrigation water retention basins by immunofluorescence colony-staining. European Journal of Plant Pathology 108: 539-545.

Sarkar SF, Guttman DS 2004. Evolution of the core genome of Pseudomonas syringae, a highly clonal, endemic plant pathogen. Applied and Environmental Microbiology 70: 1999-2012.

Vanneste JL, Cornish DA, Yu J, Boyd RJ, Morris CE 2008. Isolation of copper and streptomycin resistant phytopathogenic Pseudomonas syringae from lakes and rivers in the Central North Island of New Zealand. New Zealand Plant Protection 61: 80-85.

Vanneste JL, Cornish DA, Yu J, Voyle MD 2002. P10c: a new biological control agent for control of fire blight which can be sprayed or distributed using honey bees. Acta Horticulturae 590: 231-236.

Vanneste JL, Yu J 2006. Detection of Pseudomonas syringae pv. papulans in apple budwood. New Zealand Plant Protection 59: 146-149. 